\title{
The Relationship between Noise Intensity and Hearing Function Disorder in Ground Handling Workers at Kualanamu International Airport
}

\author{
Safrina Ramadhani ${ }^{1}$, Gerry Silaban ${ }^{2}$ \\ Department of Occupational Health \\ Faculty of Public Health, University of Sumatera Utara \\ Medan, Indonesia \\ safrinaramadhani.sr@gmail.com \\ gerry_fkmusu@yahoo.com
}

\author{
Wirsal Hasan ${ }^{3}$ \\ Departmenet of Envirnomental Health \\ Faculty of Public Health, Universityof Sumatera Utara \\ Medan, Indonesia \\ wirsal_hasan@yahoo.com
}

\begin{abstract}
Noise is all unwanted sounds sourced from the tools of production process or work tools that in some degree may cause hearig function disorder. Noise with treshold level value (TLV) of $85 \mathrm{~dB}$ is considered safe for most workers when they are working 8 hours per day or 40 hours per week.The objective of the research was to find out the influence of noise intensity on workers hearing function disorder. The research used quantitative method with cross sectional design. Noise data were gathered by using Sound Level Meter and hearing function disorder data with Audiometry test. The population of this study amounted to 128 people with samples taken amounted to 55 pepole Bivariate data analysis with $\mathrm{Chi}$ Square test $(\alpha=0.05)$. The result of the research showed that noise intensity in the apron area supaseed TLV (Leq=101 dB). Thirty five respondents worked on noisy working environment. A total of 36 respondents (65.5\%) of all samples had hearing function disorder. It was found that there was significant influence of noise intensity $(\mathrm{p}=0.001)$ with hearing function disorder $(\mathrm{RP}=42.667 \% ; 95 \%$ CI=8.505-214,043). Based on the result of study, it is recommended that the company management provide health counseling about the danger of noise, do health examination regularly, provide and require the use of personal protective equipment (PPE) for the workers.
\end{abstract}

Keywords-Noise; Noise Intensity; Hearing Function Disorder; Ground Handling; Airport

\section{INTRODUCTION}

The Law of the Republic of Indonesia Number 1 Year 1970 on Occupational Safety has regulated the safety of work in all workplace, wheter on land, in the soil, on the surface of water, in the water or in the air, within the territory of the Republic of Indonesia. Every worker shall be entitled to protection for his safety in the conduct of welfare work and to increase national production and productivity. Safety is useful to prevent and reduce accidents; prevent and count the incidence of occupational diseases both physical and psychological; and provide self-protection tools to workers; will be useful to protect workers. Each type of work certainly has a risk or potential danger caused by the physical work environment such as noises [1].
Noise, according to Permenakertrans (Per.13/Men/X/2011) are all unwanted sounds that come from the means of the production process and/or work tools that to some degree may cause hearing function disorder. Noise with a threshold value of $85 \mathrm{~dB}$ is considered safe for most workers when working 8 hours per day or 40 hours per week [2].

The noisy work environment is certainly potential with the occurrence of hearing function disorder. More than $5 \%$ of the world's population of 360 million people have experienced hearing function disorder according to WHO data in 2017. Three hundred and twenty-eight million of them are adults [3]. According to data from Riskesdas of the Republic of Indonesia in 2013, the prevalence of hearing function disorder nationwide is 2.6 percent. One of the causes of hearing function disorder is due to excessive noise exposure, including noise at work [4].

Yadnya I.W.P found results at ground handling officers at Ngurah Rai Airport Bali showed that the average noise level in the Administration Section every day ranged from 49.6 dBA-52 dBA, whereas in the Engineering Division averaged 88.3dB-93.5 dB per day. The decreased hearing threshold of ground handling officer as many as 23 people with the average officer working period more than 20 years [5].

Based on the phenomenon above, ground handling workers at Kualanamu International Airport will potentially experience hearing function disorder due to the airport apron as a high noise intensity work environment. This risk is obtained by workers with noise sources derived from aircraft engines and auxiliary engines around the aircraft, such as Ground Power Units, Airconditioning Trucks, Air Stater, and others.

This study aims to determine the relationship of noise intensity with hearing function disorder in ground handling workers

\section{METHODS}

The type of research used in this research is a quantitative method with Cross-Sectional design, where a research aimed to study the dynamics of correlation between risk factors with effects, by approach, observation or data collection at the same time. The research was conducted at Kualanamu 
International Airport for four months, ie from May to August 2017.

The population of this research were ground handling workers at Kualanamu International Airport which amounted to 128 people and the entire population met the criteria of research and male sex. The number of samples were 55 respondents. Samples were taken by using simple random sampling technique, in which the entire population had the same chance to be selected as a sample by lottery technique. If the respondent was not present or refused to be researched, then the respondent was replaced with another sample with the same technique. Respondents who participated in this study had the following criteria, 20-40 years; working over 3 years; had no history of the congenital disease in the ear, and had no head and ear trauma that might affect hearing function.

The independent variable in this research was noise intensity and dependent variable in this research was the hearing function disorder in ground handling workers at Kualanamu International Airport. The noise intensity data were obtained from the measurement with a sound level meter while the hearing function disorder was obtained through the audiometric measurement result at the ground handling worker at Kualanamu International Airport. Audiometric measurements were performed by ENT (Ear, Nose, Throat) doctors and assisted by officers who had been certified in the audiometric examination. Audiometric measurements using audiometer in a soundproof room.

Univariate analysis was performed on each variable of the research result which was useful to describe the frequency distribution of each variable. In this study, univariate analysis was used to describe the distribution of noise intensity variables and hearing function disorder variables. Bivariate analysis was done by using a Chi-Square test to know the relationship between noise intensity with hearing function disorder.

\section{RESULT}

The result of this study will be explained in this section with univariate and bivariate analysis. First, univariate results are as follows:

TABLE I

FREQUENCY DISTRIBUTION OF NOISE INTENSITY BY PLACE OF MEASUREMENT

\begin{tabular}{|c|c|c|c|c|c|}
\hline \multirow[t]{2}{*}{ Location } & \multirow{2}{*}{$\begin{array}{c}\text { Measurement } \\
\text { Of }\end{array}$} & \multicolumn{3}{|c|}{$\begin{array}{c}\text { Noise Intensity } \\
\operatorname{dB}(A)\end{array}$} & \multirow[t]{2}{*}{ Category } \\
\hline & & Lmin & Lmax & Leq & \\
\hline \multirow{3}{*}{ Apron } & 1 & 91 & 107 & 101 & \multirow{3}{*}{ Noise } \\
\hline & 2 & 90 & 104 & 100 & \\
\hline & 3 & 89 & 102 & 99 & \\
\hline \multirow[t]{3}{*}{ Office } & 1 & 32 & 76 & 53 & \multirow[t]{3}{*}{ Not Noise } \\
\hline & 2 & 74 & 83 & 78 & \\
\hline & 3 & 54 & 78 & 63 & \\
\hline
\end{tabular}

Based on the above table, the measurement of noise intensity was obtained at the apron area of the airport who had the highest average noise intensity (above the threshold value) of $101 \mathrm{~dB}$, while the lowest noise intensity in the office area (below the threshold value) was $53 \mathrm{~dB}$.
TABLE II

FREQUENCY DISTRIBUTION OF NOISE INTENSITY BY GROUND HANDLING WORKERS

\begin{tabular}{|c|l|c|c|}
\hline No & Noise Intensity & $\begin{array}{c}\text { Total } \\
\text { (people) }\end{array}$ & $\begin{array}{c}\text { Percentage } \\
(\boldsymbol{\%})\end{array}$ \\
\hline 1 & Noise & 35 & 63.6 \\
\hline 2 & Not Noise & 20 & 36.4 \\
\hline \multicolumn{2}{|r|}{ Total } & 55 & 100.0 \\
\hline
\end{tabular}

Based on Table II, the number of respondents working in the noisy workplace there were 35 people $(63.6 \%)$, while the number of respondents working in the workplace was not noisy were 20 people $(36.4 \%)$.

TABLE III

FREQUENCY DISTRIBUTION OF HEARING FUNCTION DISORDER ON GROUND HANDLING WORKERS

\begin{tabular}{|c|c|c|c|}
\hline No & $\begin{array}{c}\text { Hearing Function } \\
\text { Disorder }\end{array}$ & $\begin{array}{c}\text { Total } \\
\text { (people) }\end{array}$ & $\begin{array}{c}\text { Percentage } \\
(\boldsymbol{\%})\end{array}$ \\
\hline 1 & Hearing Disorder & 36 & 65.5 \\
\hline 2 & Normal & 19 & 34.5 \\
\hline \multicolumn{2}{|c|}{ Total } & 55 & 100.0 \\
\hline
\end{tabular}

Most workers hada hearing problem, with a total of 36 people $(65.5 \%)$ and workers with normal ears were 19 people $(34.5 \%)$ (Table III). Ground handling workers who had hearing function disorder were 19 people $(52.8 \%)$ while the workers with moderate deafness were 17 people (47.2\%).

TABLE IV

CROSS TABUlation OF NOISE INTENSITY WITH HEARING FunCTION DISORDER ON GROUND HANDLING WORKERS

\begin{tabular}{|c|c|c|c|c|c|c|c|c|}
\hline \multirow{3}{*}{$\begin{array}{c}\text { Noise } \\
\text { Intensity }\end{array}$} & \multicolumn{4}{|c|}{$\begin{array}{c}\text { Hearing Function } \\
\text { Disorder }\end{array}$} & \multirow{2}{*}{\multicolumn{2}{|c|}{ Total }} & \multirow{3}{*}{$P$} & \multirow{3}{*}{$\begin{array}{c}\text { OR } \\
(95 \% \\
\text { CI })\end{array}$} \\
\hline & \multicolumn{2}{|c|}{$\begin{array}{l}\text { Hearing } \\
\text { Disorder }\end{array}$} & \multicolumn{2}{|c|}{ Normal } & & & & \\
\hline & $\mathrm{n}$ & $\%$ & n & $\%$ & n & $\%$ & & \\
\hline Noise & 32 & 91.4 & 3 & 8.6 & 35 & 100 & 0.001 & 42.667 \\
\hline $\begin{array}{l}\text { Not } \\
\text { Noise }\end{array}$ & 4 & 20.0 & 16 & 80.0 & 20 & 100 & & $\begin{array}{l}(8.505 ; \\
214.043)\end{array}$ \\
\hline
\end{tabular}

Cross-tabulation results between noise intensity and hearing function disorder in the ground handling worker showed that from 35 people working in noisy locations there were 32 people $(91.4 \%)$ who had hearing function disorder and 3 people $(8.6 \%)$ with normal hearing. In 20 people working at no noisy sites, there were 4 people $(20.0 \%)$ who had hearing function disorder and 16 people $(80.0 \%)$ with normal hearing. The result of a bivariate test using Chi-Square test showed that $\mathrm{p}=0,001<0,05$ meaning that there was a significant influence between noise intensity with hearing function disorder in ground handling workers at Kualanamu International Airport.

\section{DISCUSSION}

The measurement results showed that the noise intensity at the airport apron location has exceeded the threshold value set by the Ministry of Manpower and Transmigration in Permenakertrans No.13 / MEN / X / 2011 on Threshold Factor 
Physics and Chemical Factors in the Workplace. The threshold value for noise intensity in the workplace should not exceed $85 \mathrm{~dB}$ in 8 hours exposure time per day. While the value of noise intensity obtained at the airport apron ranges from 100-104 dB [2].

Ground handling workers working in the working environment with noise intensity above TLV (Treshold Level Value) were $35(63.6 \%)$ workers. They work on the airport apron as GSE (Ground Support Equipment) operator, BTT (Baggage Towing Tractor) operator, ramp handling, and loading master.

The result of a bivariate test using Chi-Square test showed that $\mathrm{p}=0,001<0,05$ meaning that there was a significant influence between noise intensity to hearing function disorder in ground handling worker at Kualanamu International Airport. It is known that ground handling workers working in noisy locations had a risk of having hearing function disorder 42,667 times greater than those working in non-noise locations $(\mathrm{OR}=42,667 ; 95 \% \mathrm{CI}=8,505-214,043)$.

Yadnya (2008) in his research concluded that the noise level at Ngurah Rai Airport Bali every day ranged from 70.4 $\mathrm{dB}$ to $107.9 \mathrm{~dB}$ and there was a difference in the number of workers who experienced a sharp decrease in hearing of ground handling officers in the Engineering Division with the Administration Section [5]. Similar research was also conducted by Umeda (2010) in a company that produces boiler also explains that there is a tendency of every increase of noise intensity there is an increase of the percentage of hearing function disorder.[6] Kusmindari (2008) stated the intensity of noise causes workers to have hearing function disroder is light deafness with an average hearing threshold of $36,278 \mathrm{~dB}$ [7].

There is a significant increase in noise at work in the presence of industrialization. Hearing function disorder, especially hearing function disorder due to noise has become a common problem in a large number of workplaces. Workplaces with noise problems have different properties including textile mills, steel mills, palm oil mills, mines, airfields, sawmills, and even hospitals [8].

Noise effects can affect hearing or in organs other than hearing. Noise can be a nuisance in talks at 30-80 dB. Noise can cause hearing function disorder conduction when the tympanic membrane undergoes perforation or an oscular dislocation occurs due to a loud impulse sound. Hearing function disorder due to noise occurs due to extended exposure to $85-120 \mathrm{~dB}$. The effect on the whole body can be seen in the noisy intensity greater than $130 \mathrm{~dB}$. Hearing function disorder due to noise is the most meaningful problem facing workers in the workplace with high noise levels. The damaging effects of noise depend on the intensity of noise, the duration of exposure, the characteristics of the noisy frequency, and the individual vulnerability [8].

According to Buchari, noise can cause various disruptions to labor, such as physiological disorders, psychological disorders, communication disorders and deafness. There are also those classifying the disorder into auditory (auditory) and nonauditory disorders such as disturbed communication, safety hazards, decreased work performance, fatigue, and stress [9]. The main influence of noise to health according to Suma'mur P.K, is the damage to the sense of hearing which leads to deafness. Initially, the effect of noise on hearing is temporary and recovery occurs quickly after discontinued work in the noisy workplace. But continuous work in a noisy place results in persistent hearing function disorder and does not recover [10].

A control of the noise intensity is implemented as a safeguard against the safety and health of labor through prevention efforts. One of the controls that can be done administratively. This method is used to reduce the time of exposure of noise to the workforce by adjusting the working hours, so it is still within safe limits. In theory, this concept is very good that is by reducing the dose so that the workforce is still within safe limits. Establishing rules on job rotation is another means of administrative control recommended by $\mathrm{OSH}$ experts. Another way of establishing regulations on the necessity for the workforce to rest and eat in a special place that is not noisy. Establishing regulations on sanctions for workers who violate company regulations regarding the issue of noise hazard control is also an administrative control [11].

Employers are required to provide PPE for workers in the workplace to carry out the obligation to use PPE. Use of PPE is the last way to do to control the source of hazard (noise), so as to be able to reduce the impact of noise at work.

There are three kinds of ear protector that is earplug, earmuff, and canal caps. The use of ear protection devices in general is to protect the hearing instrument from high sound intensity (noise). The average ear plug can reduce the sound intensity by 20-30 dB at a frequency of 2,000-4000 Hz.

Employers are required to provide PPE for workers in the workplace to carry out the obligation to use PPE. Use of PPE is the last way to do to control the source of hazard (noise), so as to be able to reduce the impact of noise in the workplace.

There are three kinds of ear protector that is earplug, earmuff, and canal caps. The use of ear protection devices in general is to protect the hearing instrument from high sound intensity (noise). The average ear plug can reduce the sound intensity by $20-30 \mathrm{~dB}$ at a frequency of $2,000-4000 \mathrm{~Hz}$ [12].

\section{CONCLUSIONS}

More than a half of the respondents working at the noisy site had hearing function disorder. The noise intensity variable had a significant relationship with the hearing function disorder variable in the ground handling officer at Kualanamu International Airport.

\section{SUGGESTION}

The company management have to provide health counseling about the danger of noise. They should conduct a health examination regularly. Personal protective equipment (PPE) should be provide by the company for workers because it is very needed. Researchers suggest to ground handling officers especially, to wear ear protective equipment in order not to get hearing function disorder caused by the work undertaken. Self-awareness to wear ear protective equipment 
during work can be started from self to minimize the dangers of the work in old age. For the management of the Kualanamu International Airport, it is expected to provide personal protective equipment, especially ear protection devices, which meet the standards for each worker and require all ground handling officers to wear ear protection while working in noisy areas.

\section{ACKNOWLEDGMENT}

Thanks to Faculty of Public Health of University of Sumatera Utara, especially the lecturers of the master in public health science study program.

\section{REFERENCES}

[1] Republic of Indonesia, Law of the Republic Inodonesia Number 1 Year 1970 Occupational Safety, State Gazette of the Republic Indonesia Year 1970 Number 1. Jakarta: 1970.

[2] Minister of Manpower and Transmigration of Republic Indonesia, Per.13/Men/X/2011 Treshold Limits Physical Factors and Chemical
Factors in the Workplace, State Gazette of the Republic Indonesia Year 2011 Number 684. Jakarta: 2011.

[3] WHO. (2017) Deafness and Hearing Loss. [Online]. Available: http://www.who.int/mediacentre/factsheets/fs300/en/

[4] Agency for Health Research and Development Ministry of Health Republic of Indonesia, Basic Health Research (Riskesdas) 2013. Jakarta:2013.

[5] I.W.P. Yadnya, Noise and Sharp Levels Listen Ground Handling Officers at Bali's Ngurah Rai Airport. thesis, Bali:2008.

[6] A. Umeda, The Effect of Noise Exposure on Workers' Hearing At PT Atmindo Tahun 2010. thesis, Master Program in Environmental Science Udayana University, Medan:2011.

[7] D. Kusminsari, The Effect of Noise Intensity on the Sugu Process and the Ampelas Process for Hearing of Workers in the Wood Workshop X. thesis, Scientific Journal of TEKNO, 2008, Vol 5(2):87-96.

[8] J. Jeyaratnam, and D. Koh, Textbook of Occupational Medicine Practice, Trans., Suryadi., Ed., R.N.E. Sihombing, and P. Widyastuti., Textbook of Occupational Medicine Practice, EGC, Jakarta:2010.

[9] Buchari, Industrial Noise and Hearing Conservation Program. Lecture Papers. University of Northern Sumatra. Medan:2007.

[10] P.K, Suma'ur, Company Hygiene and Occupational Health (Hiperkes). Edition 2, Prints 1, Sagung Seto, Jakarta: 2014

[11] Anizar, Engineering Occupational Safety and Health in Industry, First Print, Graha Ilmu, Yogyakarta:2009

[12] M. Soeripti, Higiene Industri, Balai Penerbit FKUI, Jakarta:2008 